\title{
ВПЛИВ ПРИСАДОК ДО МОТОРНИХ ОЛИВ НА ХАРАКТЕРИСТИКИ ДИЗЕЛІВ, ЩО ПРАЦЮЮТЬ В НЕСТАЦІОАРНИХ УМОВАХ ЕКСПЛУАТАЦЇ̈
}

Канд. фіз.-мат. наук В.В. Аулін, асп. В.В. Слонь, канд. техн. наук Д.В. Голуб

\section{ВЛИЯНИЕ ПРИСАДОК К МОТОРНЫМ МАСЛАМ НА ХАРАКТЕРИСТИКИ ДИЗЕЛЕЙ, РАБОТАЮЩИХ В НЕСТАЦИОНАРНЫХ УСЛОВИЯХ ЕКСПЛУАТАЦИИ}

Канд. физ.-мат. наук В.В. Аулин, асп. В.В. Слонь, канд. техн. наук Д.В. Голуб

\section{INFLUENCE ADDITIVES TO MOTOR OIL ON THE CHARACTERISTICS OF DIESEL ENGINES, HAS WORKED IN THE NON-STATIONARY CONDITIONS OPER}

cand. of physics and mathematics sciences V.V. Aulin, postgraduate V.V. Slon, cand. of techn. sciences D.V. Golub

В статті розглянуто вплив присадок на зовнішньо-швидкісні характеристики дизелів, щзо працюють в нестаціонарних умовах. Виявлено збільшення рівня потужності та крутного моменту $i$ зниження питомої витрати палива при додаванні присадок дисульфід молібдена, "НИОД-5", "Roil Gold, i "КГMT-1" запропонованої авторами. Отримані результати обгрунтовуються впливом присадок на характеристики та властивості моторної оливи, ї̈ зношувальну здатність та припрацьованість основних спряжень дизелі. Визначено також відновлюваний характер властивостей оливи при додаванні присадок, щзо підтверджують експериментальні дослідження зміни моменту тертя з напрацюванням в різних режимах функціонування: безперервному $i$ "пускзупинка".

Ключові слова: нестаціонарні умови, дизель, моторна олива, присадки, потужність, крутний момент, питома витрата палива, момент тертя.

В статье рассмотрено влияние присадок на внешне-скоростные характеристики дизелей, работающих в нестационарных условиях. Выявлено, что при добавлении присадок дисульфид молибдена, "НИОД-5", "Roil Gold", и "КГМТ-1" предложенной авторами, увеличивается уровень мощности и крутящего момента и снижается удельный расход топлива. Полученные результаты обосновываются влиянием присадок на характеристики и свойства моторного масла, его изнашиваюшую способность и приработку основных сопряжений дизеля. Восстановительный характер свойств масла при добавлении присадок, подтверждается экспериментальными исследованиями изменения момента трения с наработкой в различных режимах функционирования: непрерывном и "пуск-остановка".

Ключевые слова: нестацииоарные условия, дизель, моторное масло, присадки, мощность, крутящий момент, удельный расход топлива, момент трения.

The article considers the influence of additives on the externally-speed characteristics of diesel engines operating under transient conditions. Investigations were carried out on the break-in-roller stand KC-276-032 to validate the running-in and testing of diesel engines in the cold no-load and hot -load and no load. Testing procedures and evaluate the performance of the engine. In the basic engine oil added various functional additives in optimum concentrations. Speed range crankshaft commensurate with the operational range. Tests were carried out in a continuous mode, and the "start-stop". Revealed that the addition of molybdenum disulphide additives, "НИОД-5", "Roil Gold", and "КГМТ-1" suggested by the 
authors, increased levels of power and torque and reduced fuel consumption. The findings substantiate the influence of additives on the characteristics and properties of the engine oil, it wears capacity and runningmates main diesel. Restorative properties of the oil with the addition of additives, is supported by experimental studies of changes in the friction torque with operating in different modes of operation: continuous and "start-stop". In the used motor oil without making the test additives friction torque peaks recorded in a continuous mode and in the "start-stop". When making additive remained initial peak friction torque in continuous operation at the beginning of each period mode "start-stop". To some extent reduce the overall level of the friction torque value. The characteristic is that the moment of friction in the reduction of oil additives of magnitude lower than in the continuous mode.

Keywords: non-stationary conditions, diesel, motor oil, additives, power, torque, fuel consumption, frictional torque.

Вступ. До нестаціонарних умов експлуатації дизелів транспортних засобів (Т3) можна віднести: знакозмінні навантаження; різні режими тертя ресурсовизначальних спряжень деталей; безперервний режим роботи та режим "пуск-зупинка"; складний профіль автомобільних доріг (спуски і підйоми 3 великими кутами нахилу, наявність серпантинів, затяжних поворотів $\mathrm{i}$ т. д.); переважний рух Т3 з вантажем на підйомі та спуску; рух по тимчасових автомобільних дорогах 3 щебеневим покриттям і 3 неякісним станом; істотна запиленість; невеликі дистанції пробігу; низька швидкість руху i великі навантаження та ін. [1]. У нестаціонарних умовах експлуатації переважно працюють: мобільна сільськогосподарська техніка; кар'єрні самоскиди; автомобілі 3 приводом навісного обладнання; автомобілі дорожньо-будівельної техніки; мобільна аеродромна техніка, спецтехніка та ін. [2].

Нестаціонарні умови безпосередньо впливає на зміну технічного стану деталей, їх спряжень та дизеля в цілому, його характеристики та спрацювання спряжень деталей; вплив їх на погіршення стану, характеристик і властивостей моторної оливи [3].

Дослідження динаміки змін характеристик дизелів в безперервному режимі i режимі "пуск-зупинка" безумовно $\epsilon$ актуальним і дає можливість розробити заходи, що підвищують експлуатаційну надійність Т3, покращують якісні показники i властивості моторної оливи та подовжують термін іiі використання.

Постановка проблеми у загальному вигляді та іiї зв'язок із важливими науковими та практичними завданнями. Моторні оливи при роботі в дизелях піддаються комплексній дії високої температури, кисню повітря, продуктів згоряння палива i зношування деталей основних спряжень самого двигуна, сторонніх домішок, що потрапляють через впускний колектор. Це обумовлює погіршення якості оливи, яке полягає у зміні фізико-хімічних характеристик властивостей та зменшенні періоду її експлуатації $[4,5]$.

Нестаціонарність умов експлуатації приводить до необгрунтованого зменшення тривалості ТО та використання олив 3 незадовільними функціональними властивостями i показниками якості, що обумовлює підвищений знос деталей двигуна i виходу їх з ладу $[6,7]$.

Разом 3 тим не достатньо досліджено роль присадок в нестаціонарних умовах функціонування дизелів Т3, їх взаємодія 3 базовою моторною оливою та ступінь спрацювання, вплив на показники зовнішньої швидкісної характеристики i ефективність роботи дизеля і ТЗ в цілому $[8,9,10]$.

Аналіз останніх досліджень і публікацій. 3 напрацюванням якісні показники моторної оливи дизелів погіршується. Щоб покращити фізико-хімічні показники і комплекс властивостей до базової моторної оливи додають різні функціональні присадки. Ці питання відображені в роботах вчених Є.С. Венцеля, В.П. Волкова, В.А. Войтова, Д.П. Журавля, В.В. Єфімова, I.C. Наглюка, Л.И. Погодаева, О.В. Розбаха [3, 6, 9, 11-13]. При цьому заходи по подовженню ресурсу оливи запропонували в своїх роботах В.А. Войтов, В.В. Єфімов, I.С. Наглюк, В.С. Бочаров, Д.П. Журавель та ін.

Умови експлуатації, їх вплив на довговічність дизелів та підвищення експлуатаційної надійності ТЗ враховувались в роботах вчених, але ці питання не достатньо 
обгрунтовані 3 точки зору механізму дії присадки на базову оливу і на поверхні тертя спряжень деталей, впливу на зміну зовнішньошвидкісних та техніко-економічних характеристик дизелів, що працюють в нестаціонарних умовах експлуатації $[14,15]$.

Метою даної роботи $\epsilon$ дослідження впливу присадок на зовнішньо-швидкісні характеристики дизеля в нестаціонарних умовах експлуатації.

Основна частина дослідження. Дослідженню підлягали дизелі, що працюють в нестаціонарних умовах експлуатації і встановлені на БелАЗ-75471, тягачі МЗКТ-7413, КЗКТ-7427, бульдозери Т-330, мобільна сільськогосподарська техніка (МСГТ) МТЗ-80/82, Т-150/Т-150К, мобільна аеродромна техніка МА3-546, МА3-246П, КрА3-228, спецтехніка ДЄ-224. Моторну оливу модифікували додаванням присадок "НИОД-5", "Roil Gold", "КГМТ-1" [16], дисульфід молібдена 3 оптимальними концентраціями.

Порівняльні дослідження зовнішньошвидкісних характеристик дизелів проводили на обкаточно-гальмівному стенді КС-276-032, який має наступні технічні характеристики: діапазон тиску оливи - до 1,0 МПа; температура охолоджуючої рідини $-20 \ldots 110^{\circ} \mathrm{C}$; частота обертання колінчастого вала $1000 \ldots 3250$ об/хв і вимірювання здійснюється цифровим тахометром та контролюється цифровим індикатором; максимальний навантажувальний момент - до $1850 \mathrm{H} \cdot \mathrm{m}$; та ін. Стенд дозволяє проводити припрацювання i випробування дизелів в режимах: в холодному, в гарячому без навантаження, в гарячому 3 навантаженням.

Тривалість стендових випробувань становила 150 годин. В процесі випробувань задавали максимальну потужність дизеля, вимірювали частоту обертання колінчастого валу $\omega_{i}$ та обчислювали такі характеристики як потужність, крутний момент і питому витрату палива за формулами:

- потужність $N$, кВт:

$$
N\left(\omega_{i}\right)=N_{\max } \cdot\left(\frac{\omega_{i}}{\omega_{\max }}\right) \cdot\left[a+b \cdot\left(\frac{\omega_{i}}{\omega_{\max }}\right)-\left(\frac{\omega_{i}}{\omega_{\max }}\right)^{2}\right] \cdot 1000,
$$

де $\omega_{i}$ - швидкість обертання колінчастого валу;

$\omega_{\max }$ - максимальна швидкість обертання колінчастого валу;

$N_{\max }$ - максимальна потужність дизеля;

$a, b$ - емпіричні коефіцієнти;

- крутний момент $M_{k}, \mathrm{H} \cdot \mathrm{м}$ :

$$
M_{k}\left(\omega_{i}\right)=1000 \cdot \frac{N\left(\omega_{i}\right)}{\omega_{i}}
$$

де $N\left(\omega_{i}\right)$ - функція зміни потужності дизеля.

$$
\text { - питома витрата палива } \mathrm{g}\left(\omega_{i}\right)
$$

визначалась 3 формулою:

$$
\mathrm{g}\left(\omega_{i}\right)=g_{n} \cdot\left(a-b \cdot\left(\frac{\omega_{i}}{\omega_{\max }}\right)+c\left(\frac{\omega_{i}}{\omega_{\max }}\right)^{2}\right),
$$

$g_{n}$ - максимальна питома витрата палива;

де

$a, b, c$ - емпіричні коефіцієнти.

Результати стендових досліджень залежностей потужності, крутного моменту i питомих витрат палива від частоти обертання колінчастого валу представлено на рис. 1.

Можна бачити, що додавання досліджуваних присадок в моторну оливу забезпечує стійке підвищення потужності двигуна на $100 \ldots 125$ кВт при частотах обертанні колінчастого валу більших 345 об/хв. До цієї частоти потужність дизеля майже не відрізняється. При частоті обертання, що становить 1100 об/хв. при додаванні присадки дисульфіда молібдена потужність становить 450 кВт, "НИОД-5"- 390 кВт, "Roil Gold" 380 кВт, "КГМТ-1" - 360 кВт, а для базової моторної оливи - 325 кВт. Можна бачити, що збільшення потужності залежить від типу присадки. 
a)

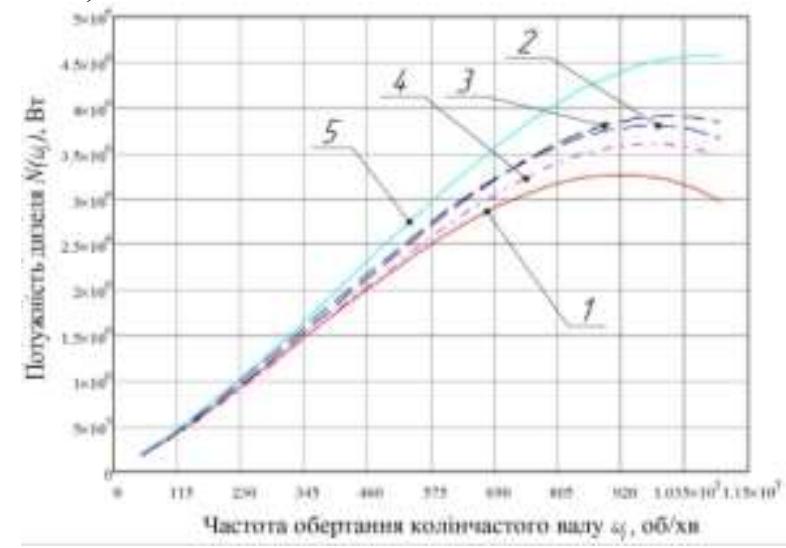

б)

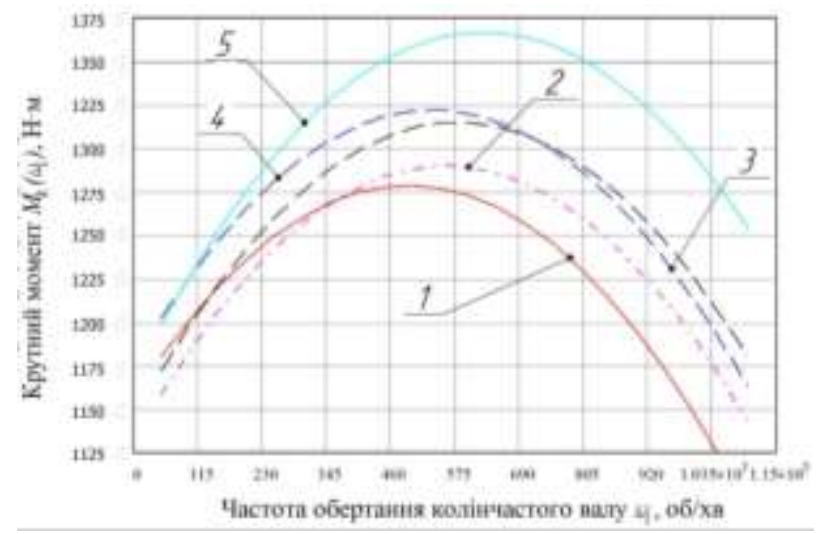

в)

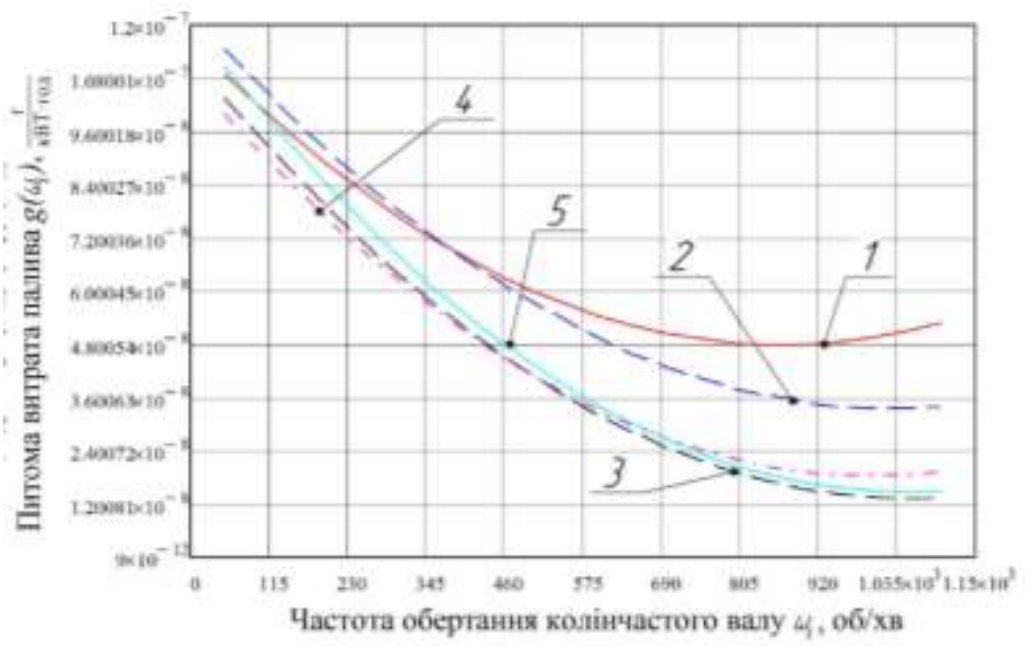

1 - базова моторна олива М10Г

3 - "RoilGold"; 4 - "КГМТ-1"; 5 - дисульфід молібдена

Рис. 1. Зовнішня швидкісна характеристика дизеля ЯМЗ-240:

a - крутний момент; б - номінальна потужність; в - питома витрата палива

Збільшення крутного моменту при додаванні присадок у порівнянні з базовою моторною оливою склало на $20 \ldots 90 \mathrm{H} \cdot$ м, зокрема дисульфід молібдена - 90 Н·м, "НИОД-5" $50 \mathrm{H} \cdot \mathrm{M}, \quad$ "Roil Gold" - $40 \mathrm{H} \cdot \mathrm{M}$, "КГМТ-1" $20 \mathrm{H} \cdot$ м. Спостерігається також зниження питомої витрати палива зниження питомої витрати палива становить, обумовлене підвищенням ефективної потужності при використанні досліджуваних присадок. При максимальній частоті обертання 1100 об/хв., для присадки "НИОД-5" становить на 10\%, "КГМТ-1" - на 20\%, a "Roil Gold" і дисульфід молібдена - на $22 \%$.
Результатами досліджень визначено зміну структури характеристик та властивостей модифікованої моторної оливи зазначеними присадками $[17,2,4]$. Змінюється і мастильна здатність модифікованих присадкою моторних олив, що підтверджують результатом досліджень момента тертя на машині тертя 3 електронним блоком керування [14]. Крім цього проведені дослідження момента тертя при мащенні спрацьованою оливою та модифікованою спрацьованою оливою М10Г 2 к.

Результати зміни момента тертя 3 напрацюванням наведені на рис. 2 . 
a)

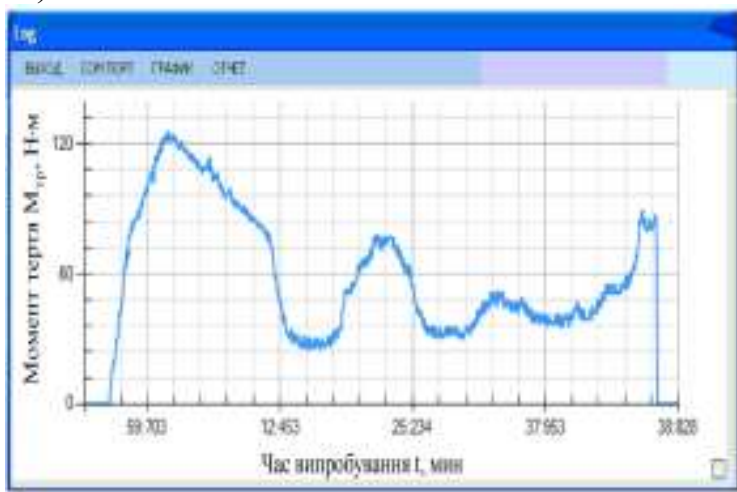

B)

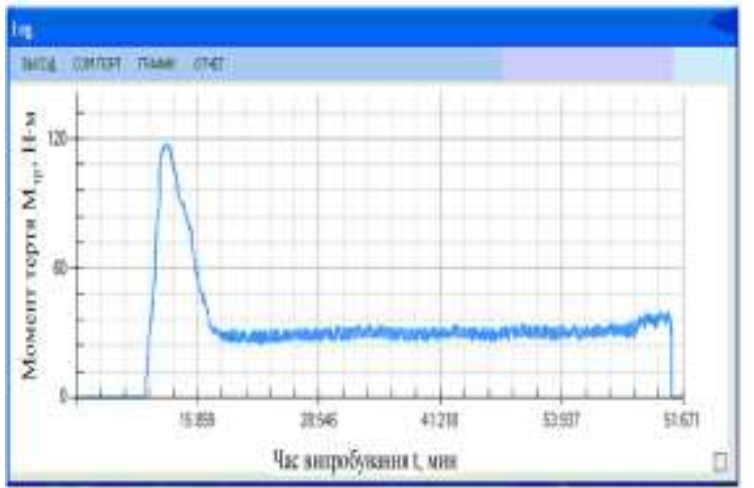

д)

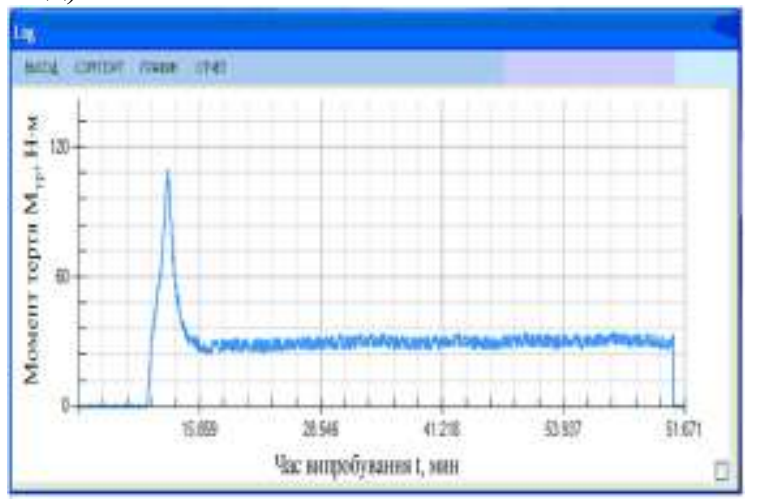

б)

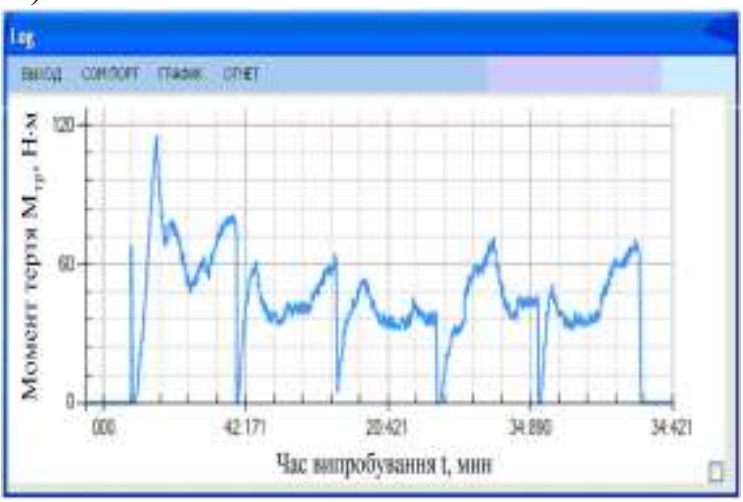

г)

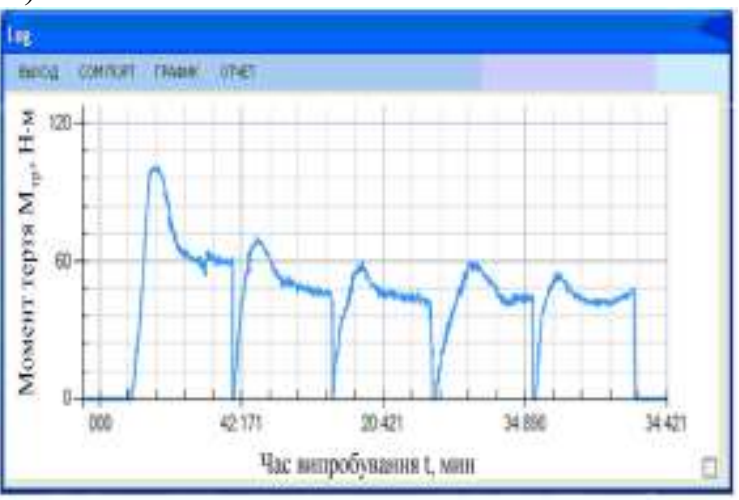

e)

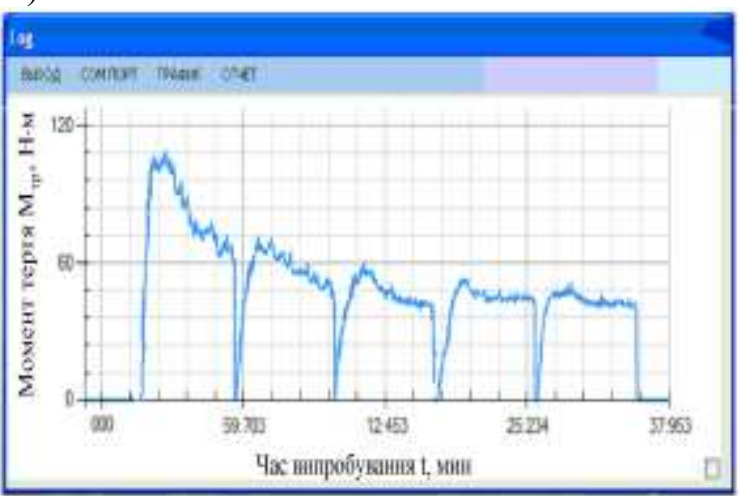

Рис. 2. Залежність моменту тертя спряжених зразків на спрацьованій оливі без додавання присадок (a, б) та $з$ додаванням присадок (в, г, д, е, є, ж, 3, и) в безперервному режимі випробування ( $\mathrm{a}, \mathrm{B}$, д, $\epsilon, 3)$ i режимі "пуск зупинка" $(б, \Gamma$, е, ж, и); (в, г) - моторна олива М10Г 2 К+"Ниод-5" (аркуш 1) 
$\epsilon)$

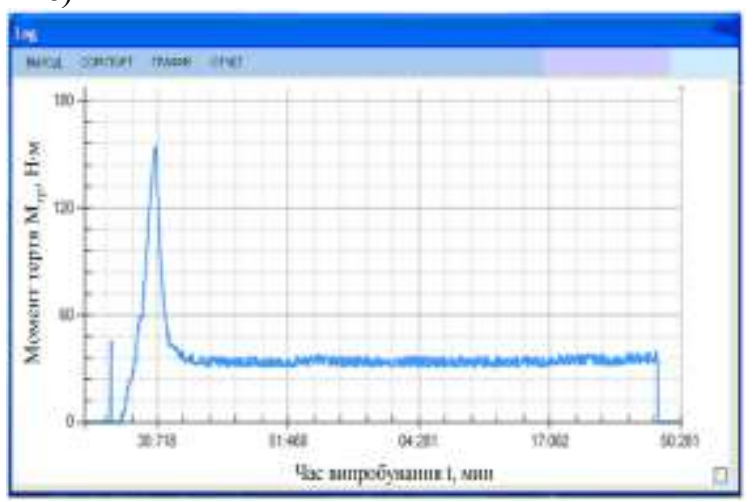

3)

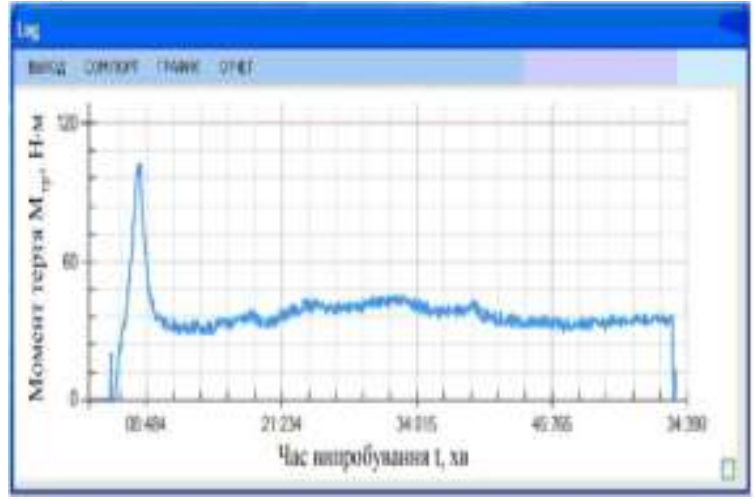

ж)

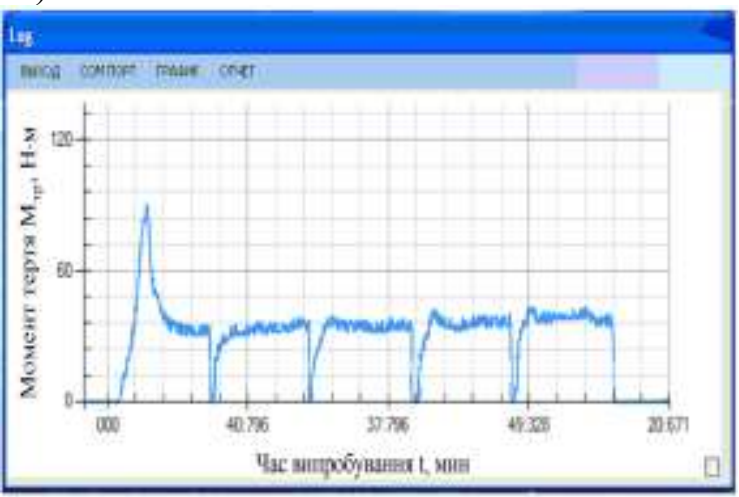

и)

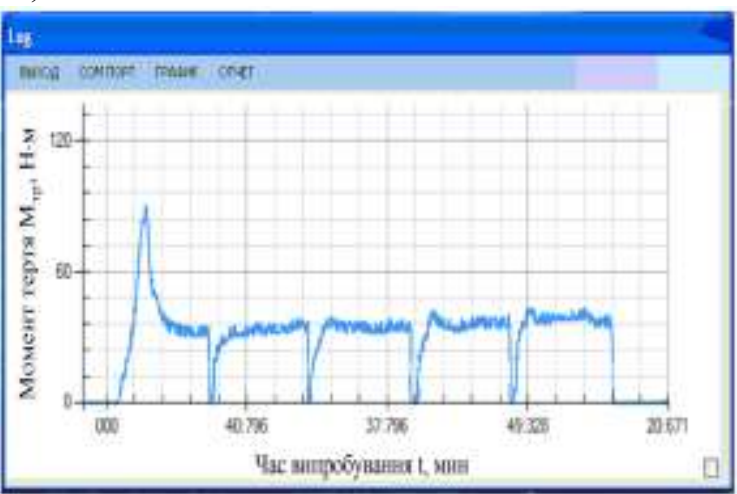

Рис. 2. Аркуш 2: (д, е) - моторна олива М10 $\Gamma_{2}$ К+"Roil Gold";

$\left(\epsilon\right.$, ж) - моторна олива М10Г 2 К+"КГМТ-1" $\left(3\right.$, и) - моторна олива М10Г ${ }_{2}$ К дисульфід молібдену

Можна бачити, що момент тертя змінюється 3 напрацюванням випадковим чином як в безперервному режимі (рис. 2,a), так i "пуск-зупинка" (рис. 2,б). Відновлювальний характер впливу присадок на зміну моменту тертя спрацьованої моторної оливи спостерігається у випадках, наведених на рис. 2, в-и.

При цьому момент тертя, як трибо технічна зменшується, але за різною закономірністю в безперервному режимі та режимі "пуск-зупинка". В останньому режимі $\epsilon$ невеликі проміжні піки моменту тертя, а при додаванні присадки "КГМТ-1" ї відсутність, i більший рівень величини моменту тертя у порівнянні 3 безперервним режимом, обумовлені діями частинок зносу у спрацьованій оливі.
Висновки 3 дослідження і перспективи, подальший розвиток у даному напрямку. Аналіз зовнішньої швидкісної характеристики двигуна свідчить, що додавання досліджуваних присадок в моторну оливу забезпечує стійке підвищення потужності, крутного моменту двигуна та зменшення питомої витрати палива в залежності від частоти обертання колінчастого валу.

Виявлено, що досліджувальні функціональні присадки відновлюють характеристики і властивості моторної оливи i ї доцільно застосовувати в нестаціонарних умовах експлуатації, наприклад в режимі "пуск-зупинка". Розробка технологій відновлення ресурсу моторної оливи потребує ретельних подальших досліджень. 


\section{Список використаних джерел}

1. Аулін, В.В. Характер зміни триботехнічних характеристик спряжень дизелів при їх роботі в різних режимах [Текст] / В.В. Аулін, В.В. Слонь, С.В. Лисенко // Проблеми трибології (Problems of tribology). - Хмельницький: ХНУ, 2013. - №3 - С.89-96.

2. Аулин, В.В. Закономерности изменения показателей качества моторного масла автомобилей, работающих в нестационарных условиях эксплуатации [Текст] / В.В. Аулин, В.В. Слонь // Проблемы автомобильно-дорожного комплекса России: Эксплуатация и развитие автомобильного транспорта: материалы X междунар. заочн. науч.-техн. конф. 21 ноября 2013 г., Пенза / [редкол.: Э.Р. Домке (отв. ред.) и др.]. - Пенза: ПГУАС, 2013. - С. 22-29.

3. Ефимов, В.В. Закономерность изменения эксплуатационных свойств моторного масла в зависимости от работы спецтехники в режиме привода навесного оборудования [Текст] / В.В. Ефимов, Н.С. Захаров // Проблемы функционирования систем транспорта: Труды региональной научно-практической конференции. - Тюмень: ТюмГНГУ, 2006. - С. 79-83.

4. Аулін, В.В. Зміна фізико-хімічних показників моторної оливи дизелів автосамоскидів в процесі експлуатації [Текст] / В.В. Аулін, В.В. Слонь, О.В. Кузик // Зб. наук. праць Кіровоградського нац.. техн. університету / Техніка в сільськогосподарському виробництві. Галузеве машинобудування. Автоматизація. - Кіровоград: КНТУ, 2012. - Вип. 25, Ч. 1. - С. 98-103.

5. Севрюгина, Н.С. Обеспечение работоспособности машин в условиях эксплуатации [Текст]/ Н.С. Севрюгина // Интерстроймех-2001: Матер. междунар. науч.- техн. конф. - СПб.: СПбГТУ, 2001. - C. 210-213.

6. Ефимов, В.В. Проведение экспериментального исследования для установления оптимальной периодичности замены моторных масел для спецтехники [Текст] / В.В. Ефимов // Проблемы функционирования систем транспорта: Труды региональной научно-практической конференции. Тюмень: ТюмГНГУ, 2006. - С. 78-79.

7. Аулін, В.В. Якість працюючої моторної оливи як показник технічного стану кар'єрних самоскидів [Текст] / В.В. Аулін, В.В. Слонь, В.М. Лисенко // Зб. статей і тез міжнар. наук.-прак. конф. "Проблеми розвитку дорожньо-транспортного і будівельного комплексів", 03-05 жовтня 2013p. Кіровоград, ПП "Ексклюзив-Систем", 2013. - С. 216-219.

8. Венцель, Е.С. Улучшение качества и повышение сроков службы нефтяных масел [Текст] / Е.С. Венцель, С.Г. Жалкин, Н.И. Данько. - Харьков: УкрГАЖТ, 2003. - 168 с.

9. Журавель, Д.П. Эффективность использования восстановленных моторных масел в тракторных двигателях [Текст] / Д.П. Журавель // Труды ТГАТА. - Мелитополь, 2001. - Вип.1, т.18. - С. 24-28.

10. Погодаев, Л.И. Материалы. Пары трения ДВС. Смазочные композиции [Текст] / Л.И. Погодаев, В.Н. Кузьмин, П.П. Дудко.- СПб.: Академия транспорта Российской Федерации, 2001. $-304 \mathrm{c}$.

11. Наглюк, И.С. Оценка качества моторных масел при эксплуатации большегрузных самосвалов [Текст] / И.С. Наглюк // Вісник Донецького інституту автомобільного транспорту. - 2009. - №3. - C. 22-26.

12. Наглюк, И.С. Изменение трибологических свойств моторных и трансмиссионных масел в эксплуатации [Текст] / И.С. Наглюк // Вісник СНУ ім. Володимира Даля. - 2010. - № 6 (148). - С. 41-45.

13. Войтов, В.А. Критериальный подход для оценки служебных свойств моторных масел в процессе эксплуатации ДВС [Текст] / В.А. Войтов, В.А. Мазепа // Вестник НТУ «ХПИ»: сб. науч. тр. Тематический выпуск «Автомобиле- и тракторостроение». - Харьков: НТУ «ХПИ», 2002. - № 10, T. 1. - C. 135-138.

14. Аулін, В.В. Припрацювання трибосполучень деталей в режимі роботи "пуск - зупинка" [Текст] / В.В. Аулін, В.В. Слонь / Зб. тез матеріалів міжнар. наук.-практ. конф. «Ольвійський форум 2012: Стратегія України в геополітичному просторі» Секція «Трибологія, енерго- та ресурсозбереження», 6-10 червня 2012, Ялта., т. 12. - С.73-74.

15. Аулін, В.В. Експрес-оцінка впливу моторних олив і присадок до них на характеристики зносу робочих поверхонь деталей двигунів вантажних автомобілів [Текст] / В.В. Аулін, В.В. Слонь, С.В. Лисенко // Вісник інженерної академії України. - 2013. - №2. - С. 166-170.

16. Припрацювальна мастильна композиція [Текст]: пат. 81598 Україна, МПК (2013) С10М 125/04. / Аулін В.В., Слонь В.В., Лисенко С.В., Голуб Д.В.; заявник і патентоотримувач 
Кіровоградський національний технічний університет. - №u201213907; заявл. 06.12.2012; опубл. 10.07.13, Бюл. № 13.

17. Аулин, В.В. Влияние комбинированного физико-химического модифицирования моторного масла на изменения момента трения и потребляемой мощности в сопряжениях образцов и деталей [Текст] / В.В. Аулин // Трение и смазка в машинах и механизмах, 2014. - №2. - С.21-28.

Рецензент д-р техн. наук, професор Є.К. Солових

Аулін Віктор Васильович, канд. фіз.-мат. наук, професор кафедри експлуатації та ремонту машин Кіровоградського національного технічного університету, м. Кіровоград, Україна, просп. Університетський 8 , м. Кіровоград, Україна, 61050. тел. +38-095-055-74-11. E-mail: aulin52@ mail.ru.

Слонь Віктор Вікторович, аспірант кафедри експлуатації та ремонту машин Кіровоградського національного технічного університету, м. Кіровоград, Україна, просп. Університетський 8, м. Кіровоград, Україна. Голуб Дмитро Вадимович, канд. техн. наук, доцент кафедри експлуатації та ремонту машин Кіровоградського нац. техн. університету, м. Кіровоград, Україна, просп. Університетський 8, м. Кіровоград, Україна.

Aulin Victor Vasilivich, Cand. of Physics and Mathematics sciences, Professor, Department of "Maintenance and repair of machines", Kirovograd National Technical University,. Kirovograd, Ukraine ave. University 8 m. Kirovograd, Ukraine, 61050. tel. 095-055-74-11. E-mail: aulin52@mail.ru.

Słoń Victor Victorovich, postgraduate of "Maintenance and repair of machines", Kirovograd National Technical University, Kirovograd, Ukraine ave. University 8 m. Kirovograd, Ukraine.

Golub Dmutro Vadumovich, Cand. of techn. Sciences, Department of "Maintenance and repair of machines", Kirovograd National Technical University,. Kirovograd, Ukraine ave. University 8 m. Kirovograd, Ukraine. 